UDC 336.02:339.9

DOI: https://doi.org/10.32840/2522-4263/2020-2-36

Polishchuk Vadym

Candidate of Economic Sciences, Associate Professor, Associate Professor at the Department of Finance, Banking and Insurance, Lutsk National Technical University

Поліщук В.Г. кандидат еконолічних наук, дочент, доцент кафедри фінансів, банківської справи та страхування Луцького національного технічного університету

\title{
DANGER OF FINANCIAL AND ECONOMIC CONSEQUENCES OF COVID-19 DISTRIBUTION IN THE WORLD AND IN UKRAINE AND POSSIBLE COUNTERMEASURES
}

\section{НЕБЕЗПЕКА ФІНАНСОВО-ЕКОНОМІЧНІ НАСЛІДКІВ ПОШИРЕННЯ COVID-19 В СВITI ТА В УКРАЇНI ТА МОЖЛИВІ ЗАХОДИ ПРОТИДІї}

\begin{abstract}
ANNOTATION
The article investigated the financial and economic consequences of the dangerous coronavirus infection Covid-19. The fall in world GDP will be due to lower consumption, as well as losses in tourism, trade, consumption, the impact of the affected financial markets and a reduction in investment. If the coronavirus epidemic is not taken under control until the summer of 2020, it can lead to a decrease in global GDP growth, and especially to hit developing countries. The issue of not only finding a highly effective treatment and high-quality vaccine, but the introduction of the most effective financial levers and methods that can stop or slow down the sharp deterioration of the economic situation in the world today is becoming very urgent. It is also worth exploring the financial and economic manifestations of Covid-19 in Ukraine, since the slowdown in economic growth and the problems in the financial sector that existed before the epidemic will only aggravate and push the country to a severe recession.
\end{abstract}

Key words: Covid-19, financial policy, fiscal policy, financial and economic crisis, international economic relations.

\section{АНОТАЦІЯ}

У статті досліджено фрінансово-економічні наслідки небезпечної коронавірусної інфекції Covid-19. Зростання боргів на тлі коронавірусу Covid-19 вразило спочатку невеликі компанії, де виник вірус. На сьогодні тенденції у світі однакові: як тільки в країну приходить вірус, влада вводить ряд обмежень і малі підприємства змушені йти на карантин або закриватися, оскільки зростають виплати працівникам та постачальникам, немає коштів на виплату кредитів та сплату оренди. Також спочатку в Китаї, а тепер в інших країнах світу, уряд просить банки запропонувати більше пільгових кредитів для бізнесу. Також вводяться скасування штрафних санкцій по сплаті податків і вводяться податкові канікули на час карантину. Негативний вплив на економіку Китаю та країн, де швидко розповсюджується коронавірус Covid-19, може бути в рази більшим, і може зумовити початок глобальної економічної рецесії. Варто зазначити, що під час будь-яких епідемічних спалахів змінюється поведінка споживачів (клієнтів) і продавців. Тобто модель поведінки змінюється через прогрес/регрес епідемічного прояву хвороби. Оцінки різних аналітичних центрів свідчать, що втрати світового ВВП від поширення Covid-19 можуть скласти 8,5 трлн доларів. Збитки будуть зумовлені зниженням світового ВВП через глобальну пандемію. На сьогодні понад 170 країн світу відзначають, що у них $€$ хворі на вірус. Падіння світового ВВП буде зумовлене зниженням споживання, а також втратами в області туризму, торгівлі, споживання, ефектом від постраждалих фрінансових ринків і скорочення інвестицій. Якщо епідемія коронавірусу не буде взята під контроль до літа 2020 р., може призвести до зниження темпів росту світового ВВП, і особливо вдарити по країнах, що розвиваються. Дуже великої актуальності на сьогодні набуває питання не тільки пошуку високоефективного лікування та якісної вакцини, як впровадження максимально дієвих фінансових важелів та методів, що зможуть зупинити чи уповільнити різке погіршення економічної ситуації у світі. Варто також дослідити фінансово-економічні прояви Covid-19 в Україні, оскільки уповільнення економічного зростання та проблеми у фінансовому секторі, що існували до епідемії, лише будуть загострюватися і штовхати країну до важкої рецесії.

Ключові слова: Covid-19, фрінансова політика, фріскальна політика, фінансово-економічна криза, міжнародні економічні відносини.

\section{АННОТАЦИЯ}

В статье исследованы финансово-экономические последствия опасной коронавирусной инфекции Covid-19. Падение мирового ВВП будет обусловлено снижением потребления, а также потерями в области туризма, торговли, потребления, эффректом от пострадавших финансовых рынков и сокращение инвестиций. Если эпидемия коронавируса не взято под контроль до лета 2020, может привести к снижению темпов роста мирового ВВП, и особенно ударить по странам, которые развиваются. Очень большую актуальность сегодня приобретает вопрос не только поиска высокоэффрективного лечения и качественной вакцины, как внедрение максимально действенных финансовых рычагов и методов, которые смогут остановить или замедлить резкое ухудшение экономической ситуации в мире. Стоит также исследовать финансово-экономические проявления Covid-19 в Украине, поскольку замедление экономического роста и проблемы в финансовом секторе, существовавших до эпидемии, только будут обостряться и толкать страну к тяжелой рецессии.

Ключевые слова: Covid-19, финансовая политика, фискальная политика, финансово-экономический кризис, международные экономические отношения.

Formulation of the problem in general form and its connection with important scientific and practical tasks. As of March 24, 2020 more than 350 thousand of confirmed cases of Covid-19 were recorded in the world, a new coronavirus that arose in late December 2019 - early 2020 in China, in Wuhan, and spread worldwide (more than 250,000 outside China) [2; 4]. Along with the loss of health of thousands of people, the number of dead people is increasing. Because people are ill, 
they cannot participate in the production process. That is, businesses in China and around the world are dealing with lost revenue, and the supply chain of goods and raw materials is changing accordingly. In addition, tens of millions of people are quarantined or under observation today, and people are unable to travel and spend their free time. Therefore, it is worth exploring the danger of the financial and economic consequences of the spread of Covid-19 in the world and in Ukraine today and suggesting possible countermeasures.

Analysis of recent research and publications on which the author relies, in which he discusses this problem and approaches to its solution. It is worth noting that the coronavirus threat arose in the world in late 2019 - early 2020, and has recently become pandemic. Therefore, today there is virtually no fundamental scientific research by scientists on the dangers of the financial and economic consequences of the spread of Covid-19 in the world. There are only statements of scientists and politicians about the possible development of events. Therefore, this study is based on available information, in particular, the World Health Organization, the European Central Bank of the World Economic Forum, official information from the governments of the countries and their own scientific observation.

Formulating the goals of the article (problem statement). It is worth exploring how much economic and financial relations have changed in the world and in Ukraine in a short period of time (first quarter of 2020) under the influence of the negative effects of pandemic virus growth and the introduction of quarantine restrictions in a large number of countries. It is also worth suggesting possible ways to counter the virus and stop devastating financial and economic changes in several countries, including in Ukraine.

Presentation of the main research material with full justification of the scientific results. Due to the growth of globalization processes and the high level of trade relations between the states and China, many companies (more than 50 000) depend on the state of the economy of China or countries that have a high level of disease today.

China's economy remains the world's second-largest economy. China's share of the global economy will fall in proportion to the worldwide spread of the virus, and thus global economic growth will decline. For example, China's economic growth is likely to fall to $4.5 \%$ in the first quarter of 2020 , compared to $6.0 \%$ in the fourth quarter of 2019. Already, China's economy is running at a maximum of 50 due to a blockage caused by the effects of the coronavirus. \% . China may lose the world championship.

It is worth remembering that China is the largest importer of oil in the world today. It is already safe to say that the first drop in global oil demand will take place in the next ten years. After all, the Covid-19 coronavirus affects not only human health but also the manufacturing process and tourism. In early February, 2020, there was a $25-50 \%$ decline in industries such as oil refining, coal production and steel production. The slowdown in economic activity leads to a fall in demand for oil, and it is naturally cheaper. The same thing happens with gas.

Large companies have encountered negative manifestations of the virus. In particular, Alibaba Group Holding Ltd, China's first major technology corporation, has confirmed that the virus is disrupting the manufacturing process and changing the structure of purchases, since consumers are usually actively reducing costs that are not related to essential things.

Foxconn, an Apple manufacturing partner, has also been delayed in its production. Automobile companies such as Nissan and Hyundai have temporarily shut down their production outside China because they could not obtain spare parts. However, when the epidemic in China goes down, Apple stores will reopen. Back in late February, the company said it would not be able to meet its revenue forecast in the first quarter of 2020. Despite the fact that they resumed operations after quarantine, production recovery rates were not so high that Apple could avoid a deficit.

It is worth noting that millions of small and medium-sized Chinese firms are on the verge of survival. Only $60 \%$ of them will be able to cover regular payments within one to two months before cash runs out. And $10 \%$ of such companies said they could last six months or longer. This is a wake-up call because small and medium-sized companies in China play an extremely important role in the country's economy as they provide $60 \%$ of China's GDP. At the same time, the IMF forecast indicates that China will return to normal in Q2 2020.

A number of pharmaceutical companies are also preparing to downsize or re-profile. Today almost all entertainment and trade establishments in all countries, educational institutions in several countries, not only in China, have closed. We are also talking about the beauty, fashion, cancellation or transfer of large-scale sporting events (Euro-2020, Summer Olympic Games), film festivals, movie rental and production stops, the suspension of galleries, museums and theaters. The tourism industry has particularly suffered losses. In particular, we are talking about tens of billions of dollars. As a consequence, the transport industry, especially the revenue from air transportation, has declined at times. And some airlines have gone bankrupt (Flybe, Atlasglobal, Air Italy). Overall, airlines may lose more than 100 billion USD in revenue in 2020.

Global financial markets responded immediately to problems with the Covid-19 coronavirus. On February 24, 2020, global financial indices began to plummet amid the spread of Covid-19. The very message of the spread of the virus outside China has collapsed the securities market. The major stock markets of the Asia-Pacific region 
then closed in the red. We are talking about the Shanghai, Hong Kong, Japanese, South Korean, Australian exchanges. It was then that the virus spread outside China, in South Korea and Iran and in northern Italy.

On February 24, at the end of the day, the basic European indices started to fall. The fall was the Athens Stock Exchange. Stock trading in the US was also in the red. This applies to both S\&P and Dow Jones and Nasdaq. The latter was the most lost as the virus outbreak found an impact on global supply and economic growth. Investors are wary of the deterioration of the situation and come out of the risky assets to which many stocks refer. However, demand for safe assets is increasing and they are rising in price.

The fall of the stock indices in the world continued on March 9, 2020. At that time, stock trading in the United States briefly stopped after a sharp fall in price. After the resumption of trading, the three major US stock indices fell more than $6 \%$. This was all a consequence of the conflict between Russia and Saudi Arabia, with the result that oil prices fell by $20 \%$ to 35 USD a barrel. It was the largest drop in the day since the start of the first Persian Gulf War in 1991. Before that, Asian stock markets also fell on March 9, 2020. In addition to falling oil prices, Asian investors also responded to a sharp drop in Chinese exports, with figures showing that the Japanese economy is shrinking faster than expected. Oil companies Exxon, BP, Chevron, Shell, Deutche Bank, Credit Agricole, mining and aviation companies suffered losses.

Indeed, the root cause of the fall in oil prices is the coronavirus. Saudi Arabia's oil supply is also increasing and discounts are being offered to its customers. That is, a chain reaction took place. The following is known: the undermining of stock market positions. After that, many US oil producers can become unsustainable. But there is a big plus for consumers: reducing the price of fuel.

Along with losses of the world economy at the level of 8 trillion USD, only in the beginning of March financial markets lost more than 9 trillion dollars. The panic that arose from Covid-19 against the backdrop of the stock market crash led investors to seek protected investment tools. Traditionally, they have found them in the US debt. Demand for the US government bonds has led to a decline in their yields below $0.5 \%$ per annum. And most likely the cost will fall.

But in this situation, the gold market has improved its position and quotations of this precious metal have grown, updating the seven-year high. In the coming months, gold is expected to cost over 1800 USD. Gold has traditionally been regarded as a hedge that should protect investors from large losses on high-risk assets.

Today we have one of the most difficult financial and economic situations in the last 25-30 years. Already, it can be argued that the virus will negatively affect the global economy more than the financial crisis and the fall of 2008-2009, which was due to the collapse of the US mortgage securities market. The devastating effects of this virus can be rightly regarded as the «Spanish influenza» of the 21 st century.

It is important to note that various imbalances have accumulated in the Covid-19 in the world over a long period, and in some markets asset prices have been unreasonably high.

Even before the coronavirus crisis, Ukraine experienced problems with the placement of new portions of government bonds. The budget under $20 \%$ of January-February 2020 was also felt to be underfunded. Ukraine is also forced to comply with the IMF requirements. Thus, the crisis phenomena in the economy that have emerged (in particular against the backdrop of the collapse of financial markets abroad in Ukraine at the end of February 2020 the GDP warrants collapsed), and the Coronavirus stagnation of the economy (closures for quarantine of small and medium-sized businesses, reduction of social payments) will significantly hit on the economy of the country. All this can lead to the onset of the country's deficit in the short term.

Ukraine has not developed a stock market, and the fall in the value of shares cannot be frightened. However, our country imports more than $80 \%$ of petroleum products consumed. Reducing oil prices will be a profitable balance of payments for Ukraine.

The simultaneous expansion of new Covid-19 cases, the continuation of quarantine measures and the introduction of emergencies in several areas and the restriction or interruption of traffic [5], the transition to teleworking of thousands of small businesses, will not contribute to the development of the economy and financial system in Ukraine, so it is worth preparing for to severe trials not only of a social nature related to human diseases, but also to economic ones. For Ukraine, the situation with the spread of Covid-19 could be the beginning of a protracted socio-economic crisis, the result of which is the cessation of a number of industries, the destruction of trade and the imbalance of the economy. In fact, the country will lose its economy, recent savings, the financial sector will reduce operations.

The sectors involved in the provision of intermediary business and financial services are growing at a tremendous pace. The banking system has accumulated huge sums that do not enter the real economy. To curb the excess pressure of «excess» hryvnia mass, the National Bank of Ukraine (NBU) tripled operations with certificates of deposit three times: up to 200 billion hryvnia. The volume of loans to the economy in the best of times was $80 \%$ of GDP, but now it is not gaining $25 \%$ of GDP. Today, real manufacturers are unable to compete for domestic market credit at rates offered by deposit-taking corporations. The situation that has arisen today is threatening that we will lose foreign capital in Ukraine. The tension is that quarantine measures can be even tougher. 
It is worth noting that the country's debt continues to grow. The domestic currency will continue to depreciate in spite of the NBU's attempts to stop the fall (the forecast is 1 USD will be estimated at 35 and more Ukrainian hryvnias). This, in turn, will sway inflation. The scarcity of individual product and product groups will lead to higher prices. GDP is expected to fall $9 \%$ (this is the same as in 2015 in Ukraine). Together, against the background of the growing social crisis, this will lead to an economic recession.

Raising pensions, increasing the budget deficit is impossible now, although it is very necessary for a social position. After all, it is necessary to establish cooperation with the IMF in Ukraine. The only way to increase the amount of money to index social benefits and pensions is to print money. But when this happens, they will immediately lose their purchasing power, as inflation will increase, there will be a devaluation and the exchange rate will be much higher than 35 hryvnias for 1 USD.

The IMF refusal to provide next tranches in 2020. It will further aggravate the difficult situation. After all, without cooperation with the IMF, it will be very difficult for Ukraine to raise debt at low yields. So, the Ukrainians will face huge challenges in 2020.

The restrictive measures that are being implemented in many countries are striking in scale. In most epidemic countries, many institutions and small businesses are forced to work online and remotely, reducing production volumes. Business quarantine is especially frightening. After all, in many countries, they develop into a state of emergency or emergency. All this leads to a decrease in business activity. As a result, companies are deteriorating their financial performance forecasts, reducing product purchases, consuming less energy.

However, as a number of markets bear the brunt of the 2020 coronavirus crisis, some countries will be able to recover and improve their positions. For example, we are talking about Mexico. This US neighbor will be able to improve its manufacturing capabilities in the automotive and technology sectors. And in the coming years, many countries will be able to move their production in this country. For the past 25 years, Mexico has become one of the major exporters and manufacturers of cars, electronics, TVs and computers for the United States. The transportation takes 5 days from Mexico to New York, and 40 days from Shanghai.

Countries are gradually helping each other to combat the Coronavirus threat. The International Monetary Fund will allocate more than 50 billion USD to help countries affected by the virus. Basically, these funds will come to help poor and middle-income countries and the poor health care system. Such support is necessary and will probably not be the last of the governments of countries and international financial organizations and institutions. After all, according to research scientists 15 million people in the world can die from the virus or its consequences.

It is also worth mentioning that virtually all countries in the world, where Covid-19 is present, are beginning to change their budgets by adjusting the major expenditures for the coming year for medical and social funding. Thus, the United States has funded support for the victims of the virus in the amount of 100 billion USD. This is due in particular to the fact that the United States entered a recession, joining the rest of the world. This threatens to increase unemployment, reduce savings, and reduce GDP growth. The funds allocated will go to free virus testing for those who need it, paid family leave, paid sick leave. The US leadership is also negotiating an aid package of more than 1 trillion USD [3].

The European Central Bank has launched an emergency aid package worth 750 billion EUR. It will buy public and corporate debt in Europe, particularly in Greece and Italy. [1]. The World Bank has allocated 12 billion USD to help developing countries combat the spread of coronavirus.

It is worth understanding that the financial crisis with all its negative aspects has a number of positive possibilities. In particular, one can try to stimulate lending to the economy not speculative transactions with various securities in the stock market. You can also try to create conditions to raise additional funds in the form of capital, rather than limit them.

It is very important to understand that economic growth should be a priority in the country even when times are tough. But there is no need to constantly curb inflation. In other words, curbing inflationary processes should not be an end in itself for any government in any country.

Economic and financial crisis can be a good opportunity for debt restructuring. When countries quarantine, destroying the principle of globalization, more and more attention must be paid to domestic producers. We also need to understand that the closure of borders will help to bring home migrant workers. Many of these people have new competencies and experience. Of course, this may be necessary for the development of the economy of the countries. We also need to understand that after Covid-19 the world will be different. Digitization of all processes in countries (trade, education, government, financial sector, etc.) will become an even more prominent feature of our time. So we will get an improvement in the efficiency of all economic processes in the economy. Also, during the virus epidemic, the development of startups in various areas of the economy should be expected. After all, the remote work of many entrepreneurs and employees of non-profit organizations will require new innovative proposals and the introduction of new processes in the business.

Conclusions from this study and further perspectives in this direction. The financial behavior of people, as never before, must be rational, weighing all the threats, aware of all the dangers, but at 
the same time also such that it is not susceptible to panic and chaos. Understanding this, central banks will undertake interventions that will mitigate exchange rate fluctuations, reduce interest rates, and will give some impetus to the economy through available loans. Also, the regulation of the fiscal policy of states should be aimed at reducing tax penalties, applying tax breaks for the duration of quarantine and restrictive measures. One thing to be aware of is that if there is a coordinated and productive work of all representatives of the executive and legislative power at different levels, there is a responsible and moderate cooperation of representatives of civil society, understanding and assistance of the citizens on the difficult socio-economic situation and financial consequences, then the depth of the negative consequences of Covid -19 will be significantly lower.

\section{REFERENCES:}

1. Communication from the Commission to the European Parliament, The European Council, The Council, The European Central Bank, The European Investment Bank And The Eurogroup. Coordinated economic response to the COVID-19 Outbreak. Brussels, 13.3.2020, $\operatorname{COM(2020)~112,~final.~Available~}$ at: https://ec.europa.eu/info/sites/info/files/communication-coordinated-economic-response-covid19-march-2020_en.pdf (accessed: 23.03.2020).

2. Coronavirus disease (COVID-19) Pandemic. World Health Organization. Available at: https://www.who.int/emergencies/ diseases/novel-coronavirus-2019 (accessed: 23.03.2020).

3. Government Response to Coronavirus, COVID-19. An official website of the United States government. Available at: https:// www.usa.gov/coronavirus (accessed: 23.03.2020).
4. Linda Lacina. More than 250,000 COVID-19 cases reported outside China - Today's coronavirus news and analysis. World Economic Forum. Available at: https://www. weforum.org/agenda/2020/03/covid-19-cases-todays-coronavirus-news-and-analysis/ (accessed: 23.03.2020).

5. Prime Minister briefs on the Government measures to protect Ukrainians from COVID-19. Cabinet of Ministers of Ukraine. Available at: https://www.kmu.gov.ua/en (accessed: 23.03.2020).

\section{БІБЛІОГРАФІЧНИЙ СПИСОК:}

1. Communication from the Commission to the European Parliament, The European Council, The Council, The European Central Bank, The European Investment Bank And The Eurogroup. Coordinated economic response to the COVID-19 Outbreak. Brussels, 13.3.2020, $\operatorname{COM(2020)~112,~}$ final. Available at: https://ec.europa.eu/info/sites/info/files/ communication-coordinated-economic-response-covid19march-2020_en.pdf (accessed: 23.03.2020).

2. Coronavirus disease (COVID-19) Pandemic. World Health Organization. Available at: https://www.who.int/emergencies/ diseases/novel-coronavirus-2019 (accessed: 23.03.2020).

3. Government Response to Coronavirus, COVID-19. An official website of the United States government. Available at: https:// www.usa.gov/coronavirus (accessed: 23.03.2020).

4. Linda Lacina. More than 250,000 COVID-19 cases reported outside China - Today's coronavirus news and analysis. World Economic Forum. Available at: https://www.weforum.org/ agenda/2020/03/covid-19-cases-todays-coronavirus-newsand-analysis/ (accessed: 23.03.2020).

5. Prime Minister briefs on the Government measures to protect Ukrainians from COVID-19. Cabinet of Ministers of Ukraine. Available at: https://www.kmu.gov.ua/en (accessed: 23.03.2020). 